\title{
The Religion Clauses and Justice Brennan in Full
}

\author{
Ira C. Lupu $\dagger$
}

Justice William Brennan, a giant of our constitutioual order, deserves better than he gets from Professor Carter im this so-called tribute.' Across a wide range of constitutional problems, Justice Brennan made enduring contributions to our jurisprudence. With respect to the First Amendment's Religion Clauses, ${ }^{2}$ Justice Brennan's legacy is umque and powerful. His views are the intellectual wellspring of the "separatiomist" theory of the Religion Clauses, pursuant to which state help and hindrance to religion are both constitutionally troublesome.

Professor Carter's Article is extremely provocative and deeply troubling, because it is exactly half-true to Justice Brennan's constitutional legacy. By that I do not mean that Professor Carter asserts any falsehoods, because he does not. Indeed, I agree with much of the half-story he tells. But there are omissions in Professor Carter's account of the Religion Clauses, and im his representation of Justice Brennan's interpretation of them, that are so material that securities lawyers would call them misleading.

This Response to Professor Carter's Article is divided into three parts. Part I sketches a map of the Religion Clauses that is more expansive than the one Professor Carter draws. Professor Carter identifies neutrality and accommodationism as the alternative and exclusive possibilities for theories of the Clauses, ${ }^{3}$ but he neglects the Establishment Clause in its full dimensions and therefore overlooks separationism as a third approach.

Part II places Justice Brennan on this expanded map, because he is a promment architect of the separatiomist tradition. Although separationism

Copyright @ 1999 Califomia Law Review, Inc.

$\dagger$ Louis Harkey Mayo Research Professor of Law, George Washington University Law School. The author wishes to thank the Brennan Center and Georgetown University for the initial invitation to comment on Professor Carter's lecture, which he dehivered at Georgetown in April 1998.

1. See Stephen L. Carter, Religious Freedom as if Religion Matters: A Tribute to Justice Brennan, 87 CALIF. L. Rev. 1059 (1999).

2. U.S. Const. amend. I "Congress shall make no law respecting an establishment of religion, or prohibiting the free exercise thereof ...."). Professor Carter views these words as representing a singular Rehion Clause. See Carter, supra note 1, at 1062.

3. See Carter, supra note 1 , at 1062. 
has lost ground in the courts over the past twenty years, its premises remain central to any persuasive and overarching philosophy of the Religion Clauses. Only with respect to the question of government support for secularly valuable activities performed by religious institutions has Justice Brennan's perspective become increasingly anachronistic and unnecessarily hostile to religion.

Part III addresses most directly and explicitly Professor Carter's comments about the Constitution and the domestication of religion. $\mathrm{He}$ claims, quite correctly, that religion may be subversive of the state. ${ }^{4}$ It is precisely for that reason, however, that both encouragement and domestication of religion are necessary for the well-being of the Republic. Some version of separationism is likely to be the best strategy for success in the delicate diplomatic mission of simultaneously respecting religion and keeping it within proper bounds.

I

\section{Separationism and the Role of the Establishment Clause}

Professor Carter's Article makes the Establishment Clause disappear. He mentions the anti-establishment norm but once, only in passing, and without enthusiasm. ${ }^{5} \mathrm{He}$ hints at the inappropriateness of applying the norm to the states, ${ }^{6}$ and his only expressed concern with the dangers of establishment is harm to the established church, which will lose its power to subvert as a result of being in partnership with the state. ${ }^{7} \mathrm{He}$ asserts that the Constitution contains but one Religion Clause, ${ }^{8}$ and it is evident throughout that he believes that the sole purpose of that simgular Clause is the empowerment of religious believers, not the protection of the organized polity against such believers' religious fervor. He critiques as unreal and impossible the imagery reflected in the metaphor of the "wall of separation,", and he lumps the idea of separation with that of state neutrality toward religion, for which he expresses disdain. ${ }^{10}$

Professor Carter's views about the Establishment Clause are especially curious in light of his exquisite sensitivity to the phenomenon of religious loyalties. He asserts that many millions of Americans nrake religious devotion "the single most inportant activity of their lives."

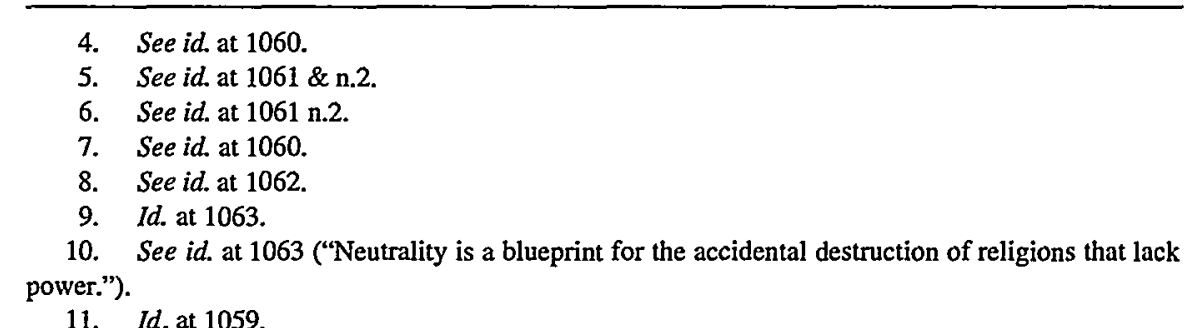

11. Id. at 1059. 
Commitments so intense and primary create issues of statecraft, ${ }^{12}$ the resolution of which are the precise function of Religion Clause principles.

Professor Carter approvingly recognizes that religious loyalties inay cause believers to challenge state policy, ${ }^{13}$ but he ignores the dangers that may follow if believers try to capture state policy in explicitly religious terms. Our existing policies concerning marriage and the lawful expression of sexuality, for example, reflect such a capture, as do public scheduling policies which privilege Christmas over all other religious holidays. In such circumstances, religious fervor may interact with competing secular and religious views of equal intensity in ways that are hazardous to political and social well-being. Constitutional norms are necessary to respond to both of these phenomena-the challenging and the capturing functions-in sensible and sensitive ways. ${ }^{14}$

Separationism as a theory of the Religion Clauses is designed to deal with the full range of problems caused by the interaction between religion and the state. Separationists recognize the diversity of religious experience, its significance to its devotees, and the socially valuable dissenting function of religion. Hence, the theory's free exercise dimension is designed to protect religion and religious institutions from destructive state regulation. Separationists also recognize, however, the hazards of capture, and accordingly design Establishment Clause norms to control and minimize those risks.

Sherbert $v$. Verner ${ }^{15}$ and Wisconsin $v . Y_{\text {Oder }}{ }^{16}$ represent the high water mark of free exercise separationism in the Supreme Court. After the Supreme Court's decision in Employment Division, Department of Human Resources v. Smith ${ }^{17}$ had undercut religion's protection, Congress enacted the Religious Freedom Restoration Act of $1993^{18}$ in order to restore an

12. The problem of conflicting loyalties to God and the state is reflected in James Madison's famous MEMorial and REMONSTRANCE AGAINST RELigious AssEsSMENTS, set forth in the Appendix to Justice Rutledge's dissent in Everson v. Board Of Education, 330 U.S. 1 (1947): "[E]very man who becomes a member of any particular Civil Society ... [must] do it with a saving of his allegiance to the Universal Sovereign." Id. app. at 64 (Rutledge, J., dissenting) (quoting JamEs MAdison, Memorial and Remonstrance Against Religious AsSessments).

13. This is the subversive outsider function, which Professor Carter applauds. See Carter, supra note 1, at 1074-85; see also Christopher Eisgruber, Madison's Wager: Religious Liberty in the Constitutional Order, 89 Nw. U. L. REv. 347, 369-77 (1995) (recognizing and approving of religion's dissenting function). Eisgruber, unlike Carter, perceives the dangers as well as the advantages of religion as a social force. See id. at 370-74.

14. I discuss this point in greater detail infra Part III.

15. 374 U.S. 398 (1963).

16. 406 U.S. 205 (1972).

17. 494 U.S. 872 (1990).

18. The Act is codified at 42 U.S.C. $\$ 2000 \mathrm{bb}$ (1994). The Supreme Court's decision in City of Boerne v. Flores, 521 U.S. 507 (1997), held the Act unconstitutional as applied to the states. Although I consider myself to some extent a free exercise separationist, see Ira C. Lupu, To Control Faction and Protect Liberty: A General Theory of the Religion Clauses, 7 J. CONTEMP. LEGAL Issues 357, $375-84$ (1996), I behieve Boerne was correctly decided, see Ira C. Lupu, Why the Congress Was Wrong and the 
element of separationism. Perhaps to distance himself from the nonestablishment meaning of "separation," Professor Carter calls this sort of protection "accommodationisn1." Whatever the label, Professor Carter in this context joins the separationists in believing that some deregulation of religion is both desirable and required by the Constitution.

Separationism, however, includes an inescapable Establishment Clause dimension. Among other things, separationism entails limitations on the state-created goods for which religious causes and institutions will be eligible. The best and most powerful exanıle of this is the constitutional principle aganist government endorsenent of religious views, ${ }^{20}$ especially im public schools im which impressionable and captive audiences are present. ${ }^{21}$ Those sanie schools may endorse a wide variety of controversial secular positions, but the Establishment Clause constrains religious speech by the government and its agents.

In such a setting, social peace depends on rigorous state neutrality with respect to religion, and no neutral criteria exist by which to measure the content of government speech on religious matters. Thus, such speech can never be understood as "nondiscriminatory" or "even-handed" in the way that financial benefits can be if such benefits are distributed without regard to the religious ideology of their recipients. Government religious speech is always a departure from religious neutrality; accordingly, the government should be barred from transmitting explicitly religious messages. Such a principle protects all religions from the danger that the state will endorse their sectarian rivals, ${ }^{22}$ and therefore helps to minimize the

Court Was Right-Reflections on City of Boerne v. Flores, 39 WM. \& MARY L. REv. 793 (1998), and 1 have substantial doubts as to the wisdom or utility of general religious liberty legislation, see Ira $\mathrm{C}$. Lupu, The Failure of RFRA, 20 U. ARK. LiTTLE ROCK L.J. 575, 597-602 (1998).

19. Carter, supra note 1, at 1062; see also id. at 1069-72 (discussing accommodationism). This is not Professor Carter's first foray into one-way separationism. See Stephen L. Carter, The Resurrection of Religious Freedom?, 107 HARv. L. REv. 118, 131-32 \& n.84 (1993) (arguing that the school praycr cases should have rested on the Free Exercise Clause, not the Establishment Clause); see also id. at 135 (arguing that government may celebrate the "secular" portions of the Christmas holiday). Conventionally understood, accommodationism refers to acts by which government removes burdens on or facilitates the exercise of religion; such acts may be either mandatory or discretionary. See, e.g., Michael W. McConnell, Accommodation of Religion: An Update and a Response to the 'Critics, 60 GEO. WASH. L. REV. 685 (1992).

20. See, e.g. , County of Allegheny v. ACLU, 492 U.S. 573 (1989) (holding that government display of a Christmas nativity scene on the staircase of the county courthouse is an unconstitutional endorsement of the religious element of Christmas).

21. See Lee v. Weisman, 505 U.S. 577 (1992); Wallace v. Jaffree, 472 U.S. 38 (1985); Abington Sch. Dist. v. Schempp, 374 U.S. 203 (1963); Engel v. Vitale, 370 U.S. 421 (1962).

22. Of course, for those who see secularism in government or culture as itself a sectarian rival, separationism of this sort is tantamount to defeat. Such a view cannot be squared with any coherent account of the Establishment Clause, because the government is always endorsing some norms and establishing its own institutions. See generally Kathleen M. Sullivan, Religion and Liberal Democracy, 59 U. CHI. L. REv. 195 (1992) (arguing that the Constitution privileges seeular norms and institutions). The Supreme Court's decision in Edwards v. Aguillard, 482 U.S. 578 (1987), which was authored by Justice Brennan, see id. at 580 , and invalidated a requirement for "balanced treatment" of creation 
incentives for religious factions to fight over the scarce resource of government support of their symbols and theologies. The resulting mutual forbearance among sects is essential to maintain the peace treaty we call the Establishment Clause.

Another long-standing example of Establishment Clause-driven separationism is reflected in the line of Supreme Court decisions regarding government aid to sectarian institutions, particularly elementary and secondary schools. ${ }^{23}$ Although separationism does not require that religious institutions be deprived of benefits, such as police and fire protection, that are provided to all enterprises in the community, government subsidies that directly finance the mission of indoctrination have long been forbidden. ${ }^{24}$ Here, too, the contrast with secular causes is stark; government may, without constitutional limitation, subsidize teaching and indoctrination in secular ideologies. Aid to private schools that teach the virtues of American citizenship, promote the desirability of democracy, or extol the advantages of capitalisn, does not raise the problems associated with aid to schools that teach the merits of Calvimism or Islam.

\section{II}

\section{Justice Brennan aNd the Separationist Tradition}

Where does Justice Brennan belong on the Religion Clause map? He surely rejected the "neutrality" approach, pursuant to which the state can help or hurt religion just as long as it similarly helps or hurts its nonreligious counterparts. ${ }^{25} \mathrm{Can}$ he be termed an "accommodationist," as Professor Carter's Article implies? ${ }^{26}$

One place to begin answering this question is with the Court's decisions involving discretionary legislative decisions to specially aid religion.

science and evolution science in public schools, is an explicit rejection of the thesis that secular and religious perspectives are constitutionally equivalent for purposes of state instruction or promotion.

23. For decisions invalidating direct transfers from states to sectarian schools, on the grounds that such transfers would impermissibly involve the state either in financing religious imdoctrination, or $\mathrm{m}$ intrusively monitoring the aid to be certain that it was not so used, see Wolman v. Walter, 433 U.S. 229 (1977); Meek v. Pittenger, 421 U.S. 349 (1975); and Lemon v. Kurtzman, 403 U.S. 602 (1971).

24. See Everson v. Board of Education; 330 U.S. 1 (1947), which suggests unmistakably in dictuin that such direct financing of elementary and secondary sectarian education is unconstitutional. See id. at 16-18. Everson's promise ripened in Lemon, 403 U.S. 602. Whatever the status of the Lemon test, the Court's recent opinion in Agostini v. Felton, 521 U.S. 203 (1997), suggests that Lemon's holding on the facts is quite secure for now.

25. Justice Brennan straightforwardly rejected formal neutrality as a free exercise principle in Employment Division, Department of Human Resources v. Smith, 494 U.S. 872 (1990), in which he joined Justice Blackmun's dissenting opinion, and part of Justice O'Connor's concurring opinion, both of which sharply criticize the theory of neutrality. See id. at 891 (O'Connor, J., concurring); id. at 907 (Blackmun, J., dissenting). He similarly rejected neutrality as an Establishment Clause norm in Mueller v. Allen, 463 U.S. 388 (1983), in which he joined Justice Marshall's dissent that explicitly repudiates formal neutrality as a governing approach. See id. at 403 (Marshall, J., dissenting).

26. See Carter, supra note 1, at 1070 n.22, 1076-77. 
It is true, as Professor Carter points out, ${ }^{27}$ that Justice Brennan wrote a concurring opinion in Corporation of the Presiding Bishop of the Church of Jesus Christ of Latter-Day Saints v. Amos ${ }^{28}$ in which the Court upheld religious institutions' statutory exemption front the federal ban on religious discrimination in hiring. But in every other case in which permissive accommodations were challenged during his Court tenure, Justice Brennan voted against them. This included the workplace protection for Sabbatarians invalidated in Estate of Thornton v. Caldor, Inc. ${ }^{29}$ and the sales tax exemption for religious reading materials invalidated in Texas Monthly, Inc. v. Bullock. ${ }^{30}$ Throw in for good neasure Justice Brennan's Court opinion in Edwards v. Aguillard, ${ }^{31}$ which invalidated Louisiana's attempt to ensure "balanced treatment" for creation science and evolution science in the public schools, and you have a record of consistent antiaccommodationism in cases in which, as Justice Brennan appraised the matter, the Constitution does not require favorable treatment for religion.

If one examines in full Justice Brennan's record in cases involving the Religion Clauses, the only possible conclusion is that he was the most committed advocate of separationism, as defined in Part I above, in the history of the Supreme Court. ${ }^{32}$ He believed very strongly in the idea of free exercise exemptions, which occasionally allow religiously-motivated actors to escape state-imposed burdens on their religious freedom. Justice Brennan was, of course, the author of Sherbert $v$. Verner, ${ }^{33}$ which is the germinal case in the conteniporary regime of free exercise exemptions. During the course of his career on the Court, he joined in every Supreme Court decision in which free exercise claims were upheld. ${ }^{34}$ Although he was, on three occasions, among a unanimous Court that rejected free exercise claims, ${ }^{35}$ Justice Brennan dissented in every nonunanimous free

27. See id. at 1076 .

28. 483 U.S. 327,340 (1987) (Brennan, J., concurring).

29. 472 U.S. 703 (1985).

30. 489 U.S. 1 (1989) (plnrality opinion). Justice Brennan wrote for the plurality in this case. See id. at 5 .

31. 482 U.S. 578 (1987).

32. Justice Souter appears to be his jnrisprudential heir in this regard. See Rosenberger v. Rcctor \& Visitors of the Univ. of Va., 515 U.S. 819, 863 (1995) (Souter, J., dissenting) (arguing that government may not subsidize a student religious journal even if it subsidizes journals animated by non-religious perspectives); Church of the Lukumi Babalu Aye, Inc. v. City of Hialeah, 508 U.S. 520, 559 (1993) (Souter, J., concurring in part) (arguing for the reconsideration of Smith and the reinstatement of a doctrine of frec exercise exemptions).

33. 374 U.S. 398 (1963).

34. In addition to Sherbert, free exercise victories in the Supreme Court during Justice Brennan's tenure include Frazee v. Illinois Department of Employment Security, 489 U.S. 829 (1989); Hobbie v. Unemployment Appeals Commission, 480 U.S. 136 (1987); Thomas v. Review Board, 450 U.S. 707 (1981); McDaniel v. Paty, 435 U.S. 618 (1978); and Wisconsin v. Yoder, 406 U.S. 205 (1972).

35. See Tony \& Susan Alamo Foundation v. Secretary of Labor, 471 U.S. 290 (1985) (requiring religious organization to adhere to Fair Labor Standards Act in a case in which the organization was involved in a commercial business); Bob Jones University v. United States, 461 U.S. 574 (1983) 
exercise decision in which the state prevailed. These include Justice Brennan's pre-Sherbert dissenting opinion in Braunfeld $v$. Brown, ${ }^{36}$ as well as his later dissents in the Lyng ${ }^{37}$ case, Goldman $v$. Weinberger, ${ }^{38} O^{\prime}$ Lone $v$. Estate of Shabazz, ${ }^{39}$ and Bowen v. Roy. ${ }^{40}$ And Justice Brennan of course dissented in Employment Division, Department of Human Resources $v$. Smith ${ }^{41}$ which to some significant extent limited the range of free exercise exemptions for which he had long fought.

Although one would never know it from Professor Carter's Article, Justice Brennan was a separationist on the Establishment Clause side as well. The single inost enduring theme to which I connect Justice Brennan in this regard concerns the topic of government religious speech, particularly in the public schools. Justice Brennan joined in Engel v. Vitale, ${ }^{42}$ the decision that invalidated daily recitals of the Regents' Prayer in public schools in New York state. He also wrote an elaborate and highly influential concurring opinion in Abington School District v. Schempp, ${ }^{43}$ which invalidated a program of Bible reading and Lord's Prayer recitation in the Pennsylvania schools. Justice Brennan understood that permitting religious speech in the public schools is likely to provoke destructive conflict aniong religious factions over the content of that speech. As he said in Abington:

It is implicit in the history and character of American public education that the public schools serve a uniquely public function: the training of American citizens in an atmosphere free of parochial, divisive, or separatist influences of any sort-an atmosphere in which children may assimilate a heritage common to all American groups and religions. This is a heritage neither theistic nor atheistic, but simply civic and patriotic. ${ }^{44}$

(upholding IRS revocation of tax-exempt status of university claiming religious reasons for racially discriminatory pohicies); United States v. Lee, 455 U.S. 252 (1982) (holding that Amish employers can be required to pay Social Security taxes, despite their religious opposition). Bob Jones involved a sacrosanct norm against minority-disadvantaging race discrimination. Both Bob Jones and Lee involved special deference to Congress in tax matters. And Alamo concerned a situation in which the burden on religion was not demonstrated. In his discussion of Bob Jones, Professor Carter makes no mention of Justice Brennan's pro-government vote. See Carter, supra note 1, at 1068.

36. 366 U.S. 599, 610 (1961) (Brennan, J., dissenting in part).

37. Lyng v. Northwest Indian Cemetery Protective Ass'n, 485 U.S. 439, 458 (1988) (Brennan, J., dissenting).

38. 475 U.S. 503, 513 (1986) (Brennan, J., dissenting).

39. 482 U.S. 342,354 (1987) (Brennan, J., dissenting).

40. 476 U.S. 693, 724 (1986) (O'Connor, J., joined by Brennan, J., concurring in part and dissenting in part).

41. 494 U.S. 872, 907 (1990) (joining the opinion of Blackmun, J., dissenting).

42. 370 U.S. 421 (1962).

43. 374 U.S. 203, 230 (1963) (Brennan, J., concurring); see also Marsh v. Chambers, 463 U.S. 783, 795 (1983) (Brennan, J., dissenting) (disagreeing with an opinion upholding prayer by the Nebraska legislative chaplain); Stone v. Graham, 449 U.S. 39 (1980) (per curiam) (invalidating a Kentucky law that required posting of the Ten Commandments in public school classrooms).

44. 374 U.S. at 241-42 (Brennan, J., concurring) (citations omitted). 
Justice Brennan's position is animated by separationist premises. He of course was concerned about protecting children who do not want to participate in a particular prayer, as well as parents who do not want their children to speak or hear that prayer because it conflicts with the parents' conception of appropriate religious training. In addition, Justice Brennan's view helps to minimize factional religious conflict by eliminating the incentives for parents to flght for the inclusion of their own faith tradition in the school's official religious pronouncements.

Justice Brennan adhered to the same theme in cases about government religious speech outside the public schools. Dissenting in Lynch $v$. Donnelly, ${ }^{45}$ for example, he argued that public support of religiouslythemed Christmas displays was socially dangerous because controversy over public adoption of religious symbols will fester whenever "communities differ in religious composition," as virtually all American communities do. ${ }^{46}$

With respect to aid to sectarian schools, Justice Brennan was an unyielding separationist, ${ }^{47}$ but his view on this subject may have outlived its time. During the first part of Justice Brennan's career on the Court, the fight about aid to sectarian schools was predominantly one between Protestants and Catholics. ${ }^{48}$ The history of Europe, and the conflicts in Northern Ireland to this day, suggest that Protestant-Catholic fights carry the potential to be extremely destructive to the state and society. Brennan, who was the only Catholic Justice during most of his tenure on the Court, surely was sensitive to this historical phenomenon.

The demography and diversity of sectarian schools, however, have changed significantly in the last several decades. Thirty years ago, Catholic schools dominated the universe of U.S. private schools; in 1970 to 1971, Catholic schools represented about $65 \%$ of all private schools and about

45. 465 U.S. 668 (1984).

46. Id. at 703-04 (Brennan, J., dissenting); see also Allegheny County v. ACLU, 492 U.S. 573, 637 (1989) (Brennan, J., concurring in part and dissenting in part).

47. See, e.g., Lemon v. Kurtzman, 403 U.S. 602, 642 (1971) (Brennan, J., concurring) (regarding salary supplements). In Mueller v. Allen, 463 U.S. 388 (1983), Justice Brennan joined Justice Marshall's dissent from a decision that upheld a state tax deduction for tuition payments to a sectarian school, see id. at 404 (Marshall, J., dissenting). Justice Brennan also wrote for the Court in Aguilar v. Felton, 473 U.S. 402 (1985), overruled by Agostini v. Felton, 521 U.S. 203 (1997). Aguilar, which revealed Justice Brennan's separationism in the extreme, held that public employees may not teach remedial subjects on the premises of sectarian schools. And he refused to accept the notion that aid to religiously affiliated colleges and universities was presumptively more acceptable than aid to elementary and secondary schools. See Roemer v. Board of Pub. Works, 426 U.S. 736, 770 (1976) (Brennan, J., dissenting); Tilton v. Richardson, 403 U.S. 672, 642 (1971) (Brennan, J., dissenting).

48. See Lemon v. Kurtzman, 403 U.S. at 628-29 (Douglas, J., concurring) (emphasizing the history and continuity of Protestant-Catholic conflict over the shape of education in America). For a more euphemistic version of the same tale, see Committee for Public Education \& Religious Liberty $v$. Nyquist, 413 U.S. 756, 768, 774, 794-98 (1973) (highlighting the predominantly Catholic character of the beneficiaries of the statute under consideration, and concluding that the scheme invited political rivalry among religious sects). 
$80 \%$ of all sectarian schools, and contained approximately $90 \%$ of all the pupils $\mathrm{n} 1$ sectarian schools in the United States. ${ }^{49}$ Explicitly attuned to that Catholic predomination, the Court's 1971 opinion in Lemon eniphasizes a traditional and stereotypical view of the highly indoctrinating character of Catholic elementary and secondary school education. ${ }^{50}$

Today, Catholic schools represent about $30 \%$ of the sectarian schools ni the United States, and contain less than $50 \%$ of the total number of students in such schools. ${ }^{51}$ Accordingly, the political divisions spawned by proposed school voucher programs or other forms of public aid to private schools no longer cluster arouud neat, sectarian lines. Because the Eurocentric concern about Protestant versus Catholic religious conflict has been aineliorated, the strict and separationist ban on state aid to sectarian schools deserves rethinking, as the Supreme Court has begun to do in the post-Brennan years. The Court is inoving away froin separationisn1 in financial aid matters now that its social rationale has weakened; the shift is evidenced by the recent overruling of Aguilar v. Felton ${ }^{52}$ in Agostini v. Felton, ${ }^{53}$ the Court's willingness in other contexts to permit state aid to students in sectarian secondary schools ${ }^{54}$ and to university students engaged in religious activities, ${ }^{55}$ and the Court's approval in Bowen $v$. Kendrick $k^{56}$ of federal grants to religious organizations for adolescent counseling.

\section{III}

\section{Religious ZeAl AND THE Religion Clauses}

The overarching thenie of Professor Carter's Article is that rights of religious freedoin are simply the rhetorical dress for state donestication of

49. See Diane B. Gertler \& IInda A. Barker, U.S. DeP'T OF Health, Educ. \& Welfare, STAtistics of NonPUblic ElementaRY aNd SecondaRY Schools, 1970-71, at 5-10 (1973).

50. See 403 U.S. at 615-20; see also id. at 635-40 (Douglas, J., concurring) (emphasizing the predominant religious mission of parochial schools, with an exclusive emphasis on Cathohic education).

51. See Stephen P. Broughman \& Lenore A. Colaciello, National Ctr. for Educ. Statistics, U.S Dep'T of Educ., Private School Universe SuRveY, 1995-96, NCES 98-229, at 5 tbl.1, 8 tbl.4 (1998), available at <http://nces.ed.gov/pubsearch/getpubcats.idc?sid=002> (visited Mar. 7, 1999). For elaboration of the significance of these demographic changes, see Ira C. Lupu, The Increasingly Anachronistic Case Against School Vouchers, 13 Notre DAME J.L. EThics \& PUB. POL'y (May 1999).

52. 473 U.S. $402(1985)$.

53. 521 U.S. 203 (1997).

54. See Zobrest v. Catalina Foothills Sch. Dist., 509 U.S. 1 (1993) (holding that supplying a publicly paid hearing interpreter to a child in a pervasively sectarian secondary school does not violate the Establishment Clause).

55. See Rosenberger v. Rector \& Visitors of the Univ. of Va., 515 U.S. 819 (1995) (holding that the Establishment Clause provides no justification for refusing to subsidize the printing costs of a religiously-oriented journal of student opmion at a state umiversity); Widmar v. Vincent, 454 U.S. 263 (1981) (holding that a student prayer club is entitled to equal access to meeting space at a state university).

56. 487 U.S. 589 (1988). 
religion. ${ }^{57}$ Religious zeal may indeed be a threat to the state, but the threat comes in two forms. First, religious observers may subvert by challenging state norms, up to and including refusal to obey them. Subversives of this sort may be good gnys, bad guys, or worse guys. Professor Carter expresses "sneaking admiration" 58 for the racist administration of Bob Jones University, but I wonder if his admiration extends to the more violent and less quaint racism of Christian white supremacist groups that organize prison inmates. ${ }^{59}$ One can of course appreciate the tenacity of subversives, and the value of their challenges to prevailing norms, without necessarily applauding their goals, condoning their means, or believing that the state should be defenseless against them. Free exercise separationism at least represents an attempt at sorting out the tolerable from the intolerable subversives, and in so domg provides an opportunity for religious subversion to seek the law's protection, as well as an occasional substantive victory for religious difference and disobedience to dominant norms. ${ }^{60}$

The second form of threat associated with religious enthusiasm arises from the zealot's urge to take over the state and use it to repress or marginalize those who hold different beliefs. Religious fervor conjoined with state power is likely to tolerate far less religious disagreement and disobedience than an enlightened secular state. However dangerous an Ayatollah may be to members of his own faith, he is almost always worse for members of others. Accordingly, separationist Establishment Clause principles are designed to prevent subversion of the state from within-that is, to prevent religious ideologues from taking over the machinery of state policy naking, backed by coercion, and using that machinery to limit the freedom and equality of those not in control.

Justice Brennan was sensitive to all of the threats presented by religious enthusiasm. He was bound and determined both to respect religious freedom when the state could manage to do so at a reasonable cost, and to minimize the danger of religious capture of state power. Professor Carter's subject is devotion to God, ${ }^{61}$ but Brennan's concerns included the maintenance and growth of the Constitution and the Republic. Accordingly, it should be no surprise that Justice Brennan's most comprehensive opinion on the subject of religion and the Constitution begins not with God, nor with recognition of the claims of believers or their religious

57. See Carter, supra note 1, at 1060-61.

58. Id. at 1068 .

59. For decisions denying claims of free exercise rights by members of such groups, see Rust $v$. Clarke, 89 F.3d 841 (8th Cir. 1996); Dickinson v. Austin, 60 F.3d 832 (9th Cir. 1995); Metheny v. Anderson, 953 F. Supp. 854 (N.D. Ohio 1996); and Haff v. Cook, 923 F. Supp. 1104 (E.D. Wis. 1996).

60. The irony, of course, is that religious subversion protectcd by the Constitution is rendered legally unsubversive by an outcome in its favor. Whatever the immediate legal outcome, religious challenge or dissent may be culturally or politicaily subversive over the long run, as the example of anti-slavery agitation reveals.

61. See Carter, supra note 1 , at 1059. 
communities, but with the great Chief Justice of the early Republic: "Almost a century and a half ago, John Marshall, in M'Culloch v. Maryland, enjoined: ' . . we must never forget, that it is a constitution we are expounding." ${ }^{2}$ So remembering, Justice Brennan could openmindedly and openheartedly entertain the claims of religious believers without blinding himself to the dangers of those assertions when they arrived at the Court cloaked in the robe of state power. Justice Brennan agreed with Professor Carter that religion matters, but Justice Brennan understood that it matters in more ways than one.

62. Abington Sch. Dist. v. Schempp, 374 U.S. 203, 230 (1963) (Brennan, J., concurring) (quoting McCulloch v. Maryland, 4 Wheat. 316, 407 (1819)). 
1116

CALIFORNIA LAW REVIEW

[Vol. 87:1105 